\title{
Anomalous subaortic position of the brachiocephalic (innominate) vein: a review of published reports and report of three new cases
}

\author{
LEON M GERLIS, SIEW YEN HO \\ From the Department of Paediatrics, National Heart and Lung Institute, London
}

SUMMARY Anomalous courses of the left innominate vein have rarely been described in $\stackrel{\circ}{-}$ anatomical specimens. Investigative techniques such as angiography and echocardiography have $\dot{\sigma}$ brought to light more instances of this anomaly. Three more cases identified by anatomical study ${ }^{T}$ are described. Earlier cases were reviewed to assess the type of associated cardiac malformations. Clinically, the abnormality is regarded as benign. When it is recognised during investigation it ${ }_{-}$ should alert the clinician to the possibility of associated malformations. Features commonly seen in $\subsetneq$ tetralogy of Fallot-right aortic arch, ventricular septal defect, and right ventricular outflow obstruction-were common in patients with anomalous subaortic innominate veins.

The left brachiocephalic (or innominate) vein extends from the junction of the left internal jugular and left subclavian veins to the junction of the right brachiocephalic (or innominate) vein and the (right) superior caval vein. The normal course is obliquely downwards and to the right, passing in front of the left subclavian, left common carotid, and brachiocephalic arteries, beneath the aortic arch. ${ }^{1}$ Very rarely, this vein (or its analogue) follows an anomalous course, passing from left to right below the arch of the aorta, to enter the (right) superior caval vein below the orifice of the azygos vein. Kershner first described this anomaly a hundred years ago, ${ }^{2}$ and we are aware of at least another 21 cases (table). We report three further cases.

Although the malformation in itself seems to be of no functional importance, we assessed its importance in terms of associated conditions and its possible relevance to subsequent operations.

\section{Case reports}

CASE 1

This girl died when she was 5 years 11 months old after cerebral ischaemia after attempted surgical correction of tetralogy of Fallot. Postmortem examination of the heart showed usual (solitus) atrial

Requests for reprints to Dr Leon M Gerlis, Department of Paediatrics, National Heart and Lung Institute, Dovehouse Street, London SW3 6LY.

Accepted for publication 20 January 1989 arrangement with concordant atrioventricular and $\overline{0}$ ventriculoarterial connections, infundibular and valvar pulmonary stenosis, subaortic ventricular septal defect, and several large aortopulmonary anastomoses. There was a right sided aortic arch. $\stackrel{\mathbb{\perp}}{\square}$ The site of the arterial duct was not apparent. The large left brachiocephalic vein passed behind the $\stackrel{3}{\exists}$ ascending aorta and below the aortic arch before entering the superior caval vein (vena cava), below the level of the azygos vein and just above its junction with the right atrium (fig 1).

\section{CASE 2}

This male infant died of complex cardiac malformation at one day. There was the usual (solitus) atrial arrangement with concordant atrioventricular connection and double outlet right ventricle with a dextroposed aortic orifice overriding a peri- $\frac{D}{0}$ membranous ventricular septal defect. There appeared to be an ectopic portion of atrioventricular $N$ valve, complete with leaflet tissue, tendinous cords, i $N$ and papillary muscles, situated between the $N$ trabecular and infundibular components of the right $\omega$ ventricle. The unguarded pulmonary artery orifice showed no trace of arterial valve leaflets. The arterial $\stackrel{\circ}{\subset}$ duct was short and widely patent. The aortic arch was $\stackrel{\oplus}{\oplus}$ left sided and had normal branches. The left internal ${ }_{+}^{+}$ jugular vein continued into a descending vein, which $\frac{0}{0}$ passed under the aortic arch from left to right, $\vec{\Phi}$ anterior to the arterial duct and between the arch and $\frac{?}{\mathbb{8}}$ the pulmonary trunk. It then ran behind the ascend- $\varrho$ ing aorta to enter the lower portion of the superior 
Table Reported cases of subaortic left brachiocephalic vein

\begin{tabular}{|c|c|c|c|c|c|c|c|c|c|}
\hline Case & Authors & Year & $\begin{array}{l}\text { Reference } \\
\text { No }\end{array}$ & Age & Sex & Diagnosis & $\begin{array}{l}\text { Relation to } \\
\text { arterial duct }\end{array}$ & $\begin{array}{l}\text { Aortic } \\
\text { arch }\end{array}$ & $\begin{array}{l}\text { Other cardiovascular } \\
\text { malformations }\end{array}$ \\
\hline $\begin{array}{l}1 \\
2 \\
3\end{array}$ & $\begin{array}{l}\text { Kerschner } \\
\text { Daser } \\
\text { Ghon }\end{array}$ & $\begin{array}{l}1888 \\
1902 \\
1908\end{array}$ & $\begin{array}{l}2 \\
6 \\
7\end{array}$ & $\begin{array}{l}? \text { (child) } \\
68 \mathrm{yr} \\
41 / 2 \text { mnth }\end{array}$ & $\begin{array}{l}\text { ? } \\
\mathbf{F}\end{array}$ & $\begin{array}{l}\text { Necropsy } \\
\text { Necropsy } \\
\text { Necropsy }\end{array}$ & $\begin{array}{l}\text { ? } \\
\text { Anterior } \\
\text { Posterior }\end{array}$ & $\begin{array}{l}\mathbf{L} \\
\mathbf{L} \\
\mathbf{R}\end{array}$ & $\begin{array}{l}\text { None } \\
\text { None } \\
\text { Absent L 4th arch, } \\
\text { isolated L subclavian } \\
\text { artery }\end{array}$ \\
\hline 4 & Nützel & 1914 & 8 & $74 \mathrm{yr}$ & $\mathbf{M}$ & Necropsy & $?$ & $\mathbf{L}$ & $\begin{array}{l}\text { Right superior } \\
\text { pulmonary vein to } \\
\text { superior caval vein }\end{array}$ \\
\hline $\begin{array}{l}5 \\
6\end{array}$ & $\begin{array}{l}\text { Martin } \\
\text { Walter }\end{array}$ & $\begin{array}{l}1931 \\
1931\end{array}$ & $\begin{array}{r}9 \\
10\end{array}$ & $\begin{array}{l}17 \mathrm{yr} \\
19 \mathrm{yr}\end{array}$ & $\begin{array}{l}\mathbf{M} \\
\mathbf{M}\end{array}$ & $\begin{array}{l}\text { Necropsy } \\
\text { Necropsy }\end{array}$ & $\begin{array}{l}\text { Anterior } \\
\text { Anterior }\end{array}$ & $\begin{array}{l}\mathbf{R} \\
\mathbf{L}\end{array}$ & $\begin{array}{l}\text { Fallot } \\
\text { Subthyroid venous } \\
\text { anastomosis }\end{array}$ \\
\hline $\begin{array}{r}7 \\
8 \\
9 \\
10 \\
11 \\
12 \\
13 \\
14 \\
15\end{array}$ & $\begin{array}{l}\text { Adachi } \\
\text { Adachi } \\
\text { Friedman } \\
\text { Roberts et al } \\
\text { Sherman } \\
\text { Sherman } \\
\text { Yoshida et al } \\
\text { Kitamura et al } \\
\text { Cloez et al }\end{array}$ & $\begin{array}{l}1933 \\
1933 \\
1945 \\
1951 \\
1963 \\
1963 \\
1975 \\
1981 \\
1982\end{array}$ & $\begin{array}{r}11 \\
11 \\
12 \\
1 \\
4 \\
4 \\
13 \\
14 \\
15\end{array}$ & $\begin{array}{l}20 \mathrm{yr} \\
41 \mathrm{yr} \\
66 \mathrm{yr} \\
7 \mathrm{yr} \\
? \\
? \\
68 \mathrm{yr} \\
69 \mathrm{yr} \\
11 / 2 \mathrm{yr}\end{array}$ & $\begin{array}{l}\mathbf{M} \\
\mathbf{M} \\
\mathbf{M} \\
\mathbf{F} \\
? \\
? \\
\mathbf{M} \\
\mathbf{M} \\
\mathbf{M}\end{array}$ & $\begin{array}{l}\text { Necropsy } \\
\text { Necropsy } \\
\text { Necropsy } \\
\text { Angio } \\
\text { Necropsy } \\
\text { Necropsy } \\
\text { Necropsy } \\
\text { Necropsy } \\
\text { Echo and angio }\end{array}$ & $\begin{array}{l}\text { Anterior } \\
\text { Posterior } \\
\text { Anterior } \\
\text { Subpulmon art } \\
\text { Anterior } \\
\text { Anterior } \\
\text { Anterior } \\
\text { Anterior } \\
\text { ? }\end{array}$ & $\begin{array}{l}\mathbf{L} \\
\mathbf{L} \\
\mathbf{L} \\
\mathbf{L} \\
\mathbf{L} \\
\mathbf{L} \\
\mathbf{L} \\
\mathbf{L}\end{array}$ & $\begin{array}{l}\text { None } \\
\text { None } \\
\text { L jugular vein anomaly } \\
\text { None } \\
\text { Pulmonary atresia VSD } \\
\text { Pulmonary atresia VSD } \\
\text { None } \\
\text { None } \\
\text { Fallot }\end{array}$ \\
\hline $\begin{array}{l}16 \\
17 \\
18 \\
19 \\
20 \\
21 \\
22\end{array}$ & $\begin{array}{l}\text { Smallhorn et al } \\
\text { Smallhorn et al } \\
\text { Smallhorn et al } \\
\text { Smallhorn et al } \\
\text { Smallhorn et al } \\
\text { Smallhorn et al } \\
\text { Smallhorn et al }\end{array}$ & $\begin{array}{l}1985 \\
1985 \\
1985 \\
1985 \\
1985 \\
1985 \\
1985\end{array}$ & $\begin{array}{l}5 \\
5 \\
5 \\
5 \\
5 \\
5 \\
5\end{array}$ & $\begin{array}{l}? \\
? \\
? \\
? \\
? \\
? \\
?\end{array}$ & $\begin{array}{l}? \\
? \\
? \\
? \\
? \\
? \\
?\end{array}$ & $\begin{array}{l}\text { Echo } \\
\text { Echo } \\
\text { Echo } \\
\text { Echo } \\
\text { Echo } \\
\text { Echo } \\
\text { Echo }\end{array}$ & $\begin{array}{l}? \\
? \\
? \\
? \\
? \\
? \\
?\end{array}$ & $\begin{array}{l}\mathbf{R} \\
\mathbf{R} \\
\mathbf{R} \\
\mathbf{R} \\
\mathbf{R} \\
\mathbf{R} \\
\mathbf{L}\end{array}$ & $\begin{array}{l}\text { Right outflow tract } \\
\text { anomalies "frequent". } \\
\text { Intra cardiac anomalies } \\
\text { in six (? VSDs). } \\
\text { Central pulmonary } \\
\text { arteries absent in one }\end{array}$ \\
\hline $\begin{array}{l}23 \\
24 \\
25\end{array}$ & $\begin{array}{l}\text { Gerlis et al } \\
\text { Gerlis et al } \\
\text { Gerlis et al }\end{array}$ & $\begin{array}{l}1988 \\
1988 \\
1988\end{array}$ & $\overline{-}$ & $\begin{array}{l}5 \text { yr } 11 \text { mnth } \\
1 \text { day } \\
7 \text { wk }\end{array}$ & $\begin{array}{l}\mathbf{F} \\
\mathbf{M} \\
\mathbf{F}\end{array}$ & $\begin{array}{l}\text { Necropsy } \\
\text { Necropsy } \\
\text { Necropsy }\end{array}$ & $\begin{array}{l}\text { No duct } \\
\text { Anterior } \\
\text { No duct }\end{array}$ & $\begin{array}{l}\mathbf{R} \\
\mathbf{L} \\
\mathbf{R}\end{array}$ & $\begin{array}{l}\text { Fallot } \\
\text { Complex } \\
\text { Common arterial } \\
\text { trunk }\end{array}$ \\
\hline
\end{tabular}

Angio, angiography; echo, echocardiography; subpulmon art, subpulmonary artery; VSD, ventricular septal defect.
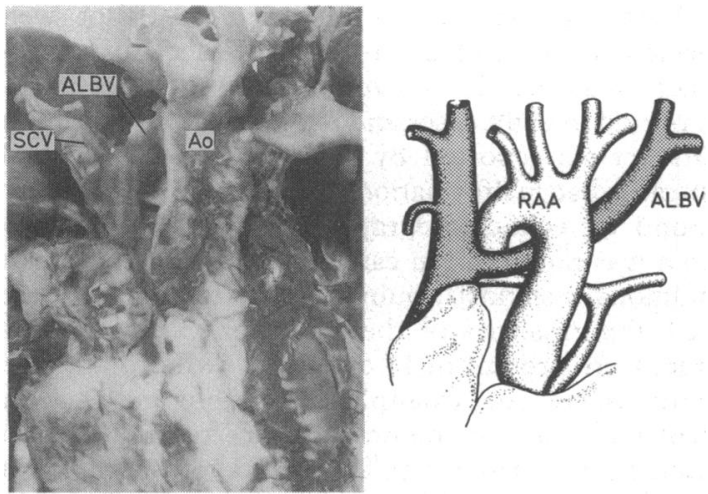

Fig 1 Photograph and diagram of case 1 showing the anomalous left brachiocephalic vein ( $A L B V$ ) running behind the ascending aorta (Ao) and below the right aortic arch ( $R A A)$ before entering the superior caval vein (SCV).

caval vein between the entry of the azygos vein and the junction with the right atrium. Because the specimen was damaged it was impossible to ascertain the connection between this anomalous vein and the left subclavian vein. There was, however, no evidence of any other route of venous drainage from the left arm (fig 2).
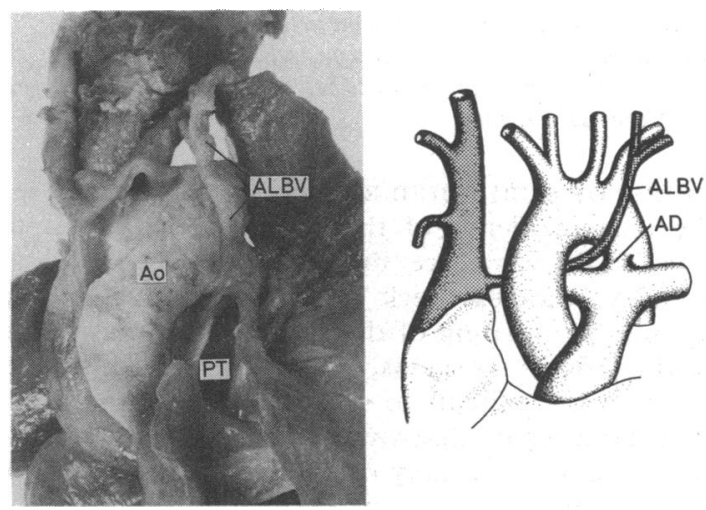

Fig 2 Photograph and diagram of case 2 showing the anomalous left brachiocephalic vein ( $A L B V)$ passing below the aorta (Ao). AD, arterial duct; $P T$, pulmonary trunk.

CASE 3

This seven week old female infant died after attempted surgical correction of a common arterial trunk. There was the usual atrial arrangement with concordant atrioventricular connection and a subtruncal ventricular septal defect with an overriding quadricuspid truncal valve. The pulmonary arteries originally had separate orifices from the posterior 
aspect of the common arterial trunk. The aortic arch was right sided and its branches were a mirror image of the normal arrangement. No arterial duct or ligament was present.

The left sided brachiocephalic vein descended to the left of the ascending aorta and then passed behind it to the right side, below the aortic arch, to open into the left medial aspect of the superior caval vein between the entry of the azygos vein and the junction with the right atrium (fig 3 ).
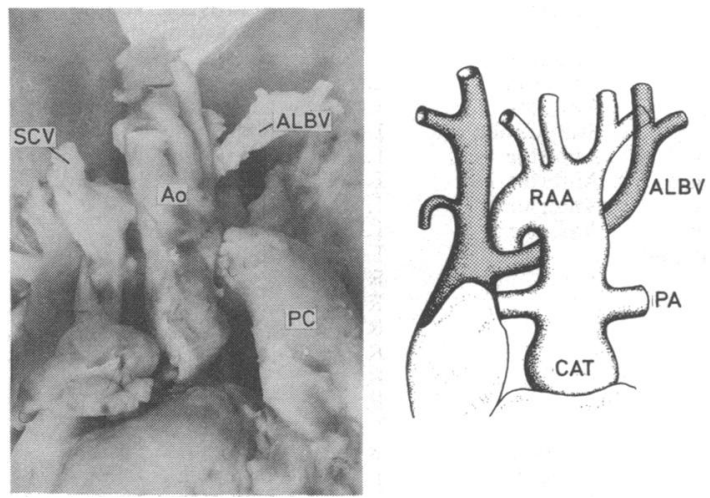

Fig 3 Photograph and diagram of case 3 showing the anomalous left brachiocephalic vein ( $A L B V)$ passing below the right aortic arch (RAA) before entering the superior caval vein (SCV). The photograph shows the vessels after surgical correction of the common arterial trunk (CAT), with the insertion of a pulmonary conduit (PC). The diagram shows the original state before operation. Ao, aorta; $P A$, pulmonary artery.

\section{REVIEW OF PUBLISHED REPORTS}

The true incidence of the anomaly is difficult to assess. The veins are rarely studied in detail at necropsy. Careless neck incisions, removal of the sternum, or opening of the pericardium may cause bleeding from the veins, which then collapse and become very difficult to see. Removal of the heart often damages or destroys the veins. Angiocardiography does not usually call for visualisation of the right brachiocephalic vein. Increased routine use of suprasternal echocardiography, however, should readily reveal the anomaly if such a possibility is recognised.

A detailed angiographic study of the brachiocephalic veins of over 1500 people showed only one example of a subaortic vein, ${ }^{1}$ while another angiographic study of the superior caval veins in 510 patients with congenital heart disease showed no such anomalies. ${ }^{3}$ Sherman found two examples among 503 specimens of congenitally malformed hearts ${ }^{4}$ and we have encountered three cases out of approximately 2000 congenitally malformed hearts

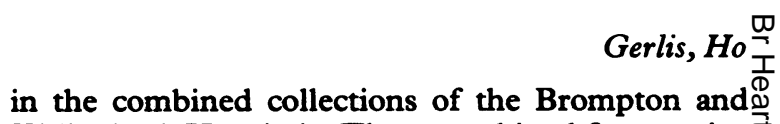
Killingbeck Hospitals. These combined figures give $c$ an incidence of six cases out of about 2500 necropsy cases with congenital heart disease, or approximately one in 500. Smallhorn et al found seven caseso echocardiographically but the total number of $\overline{=}$ patients examined in the series is not stated.

The incidence in individuals without $\operatorname{cardiac} \stackrel{\mathbb{\Phi}}{\Omega}$ malformation is presumably very much lower. In a personal necropsy series, LMG found no subaortic $\rightarrow$ brachiocephalic veins in approximately 5000 individuals without malformed hearts.

In none of the reported cases has it been suggested $\stackrel{\omega}{S}$ that the venous anomaly had any adverse physiological or clinical effect. Therefore the age at death or diagnosis was relevant only to associated or -5 unassociated conditions. The ages ranged from one day to 74 years (table). In those cases with congenitalo heart disease, the mean known age was approxi-으 mately three years (excluding a 74 year old man withan anomalous connection of the right upper $\subseteq$ pulmonary vein). In cases with normally formed hearts, the mean age at death was 53 years, support $-\vec{\oplus}$ ing the view that the abnormality is clinically benign. 0

The sex of 15 of the 25 cases was known. Males outnumbered females by 11 to 4 . Those cases witho congenital heart malformation showed no significant $\stackrel{-}{\circ}$ sex difference but all eight cases with normally. formed hearts were male.

Features common to tetralogy of Fallot were present in most of the 14 cases with major cardiaco을 malformations. Thus a ventricular septal defect was reported in eight cases and may have been present in another six reported by Smallhorn et al in which intracardiac malformations of unspecified types were $\bar{\varnothing}$ found by echocardiography. ${ }^{5}$ A right sided aortic arch was noted in ten cases and tetralogy of Fallot, $\overline{-}$ pulmonary stenosis, pulmonary atresia, or unspeci fied abnormalities of the right ventricular outflow tract were present in 11 of the 14. Other malformations were: one example of double outlet righto ventricle, one common arterial trunk, and an $>$ anomalous isolated subclavian artery arising from an을. arterial duct (see table). There were minor vascular anomalies in three additional cases in which the heart ${ }^{\circ}$ itself was normal. A 74 year old man had anomalous 0 drainage of the right superior pulmonary vein into $N$ the superior caval vein ${ }^{8} ;$ a 19 year old man had a smallo subthyroid transverse venous anastomosis, ${ }^{10}$ and ao man of 66 had minor abnormalities of the jugular vein. ${ }^{12}$ There were no instances of associated non-? cardiovascular malformations.

Three distinct anatomical varieties of the malformation can be recognised according to the relation of the anomalous vein with the arterial duct or ligament $\stackrel{\mathbb{Q}}{\stackrel{\mathrm{Q}}{ }}$ (fig 4). The presence and position of this structure 
(a)

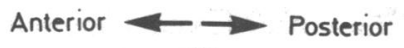

(N)

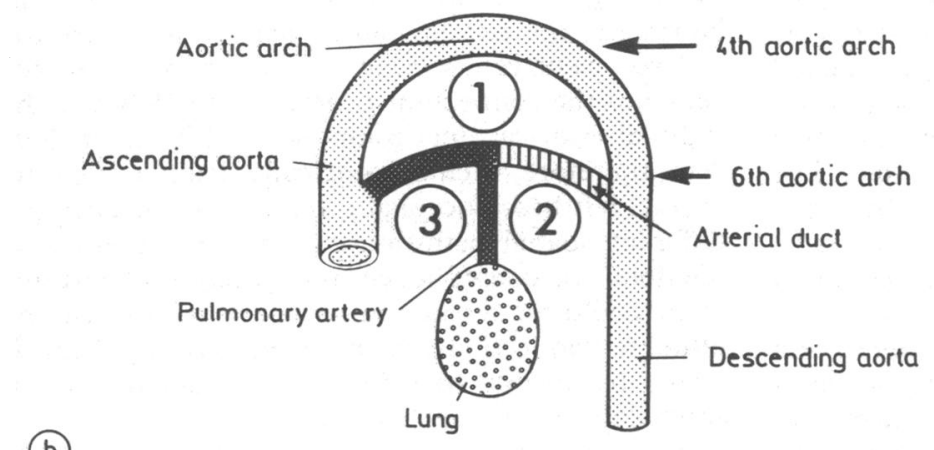

(b)
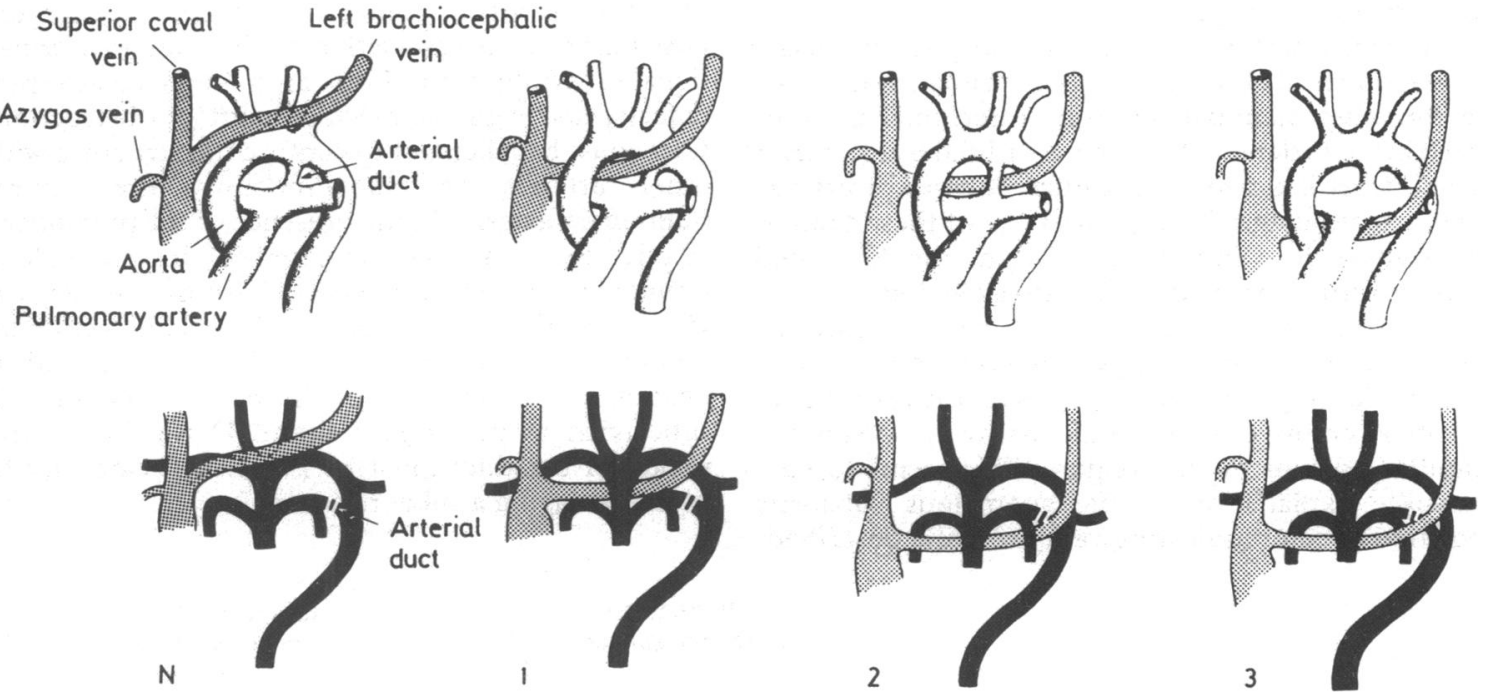

Fig 4 (a) Diagram showing the positions of the normal $(N)$ and the three variants of the anomalous left brachiocephalic vein $(1,2,3)$ in relation to the 4 th and 6 th left aortic arches as seen from the left side. (b) Diagrams of the normal and abnormal variant venous pathways as seen from the front, with accompanying embryological diagrams.

was specified or illustrated in 13 cases. In ten, the vein passed anteriorly to the arterial duct or ligament to lie between the underside of the aortic arch and the pulmonary arteries. In two cases, the vein passed posteriorly to the arterial duct or ligament, while in the remaining case it passed below the left pulmonary artery. ${ }^{1}$ Three further cases have been described in which the left brachiocephalic vein passed behind one or more of the main aortic branches but was normally related to the aortic arch..$^{45101216}$ This condition is distinct from the anomalous venous pathway that is the subject of this review.

\section{Discussion}

During normal development, the primordia of the systemic veins first appear as paired anterior and posterior cardinal veins that unite on each side to form a common cardinal vein (or cuvierian duct) that opens into the primitive sinus venosus. The anterior cardinal veins extend headwards to the junctions of the internal jugular veins and subclavian veins on each side, but, during subsequent development, most of the left anterior cardinal vein disappears. The venous drainage from the left side of the head and 
neck and the left arm is then directed into the right anterior cardinal vein by the development of a new transverse anastomotic channel that becomes the left brachiocephalic (or innominate) vein. The short part of the right anterior cardinal vein that lies distal to the opening of the left brachiocephalic vein is designated as the right brachiocephalic vein, while the portion that lies below, together with the right common cardinal vein, becomes the superior caval vein. The orifice of the (right) azygos vein represents the site of entry of the right posterior cardinal vein and marks the junction of the anterior cardinal and common cardinal venous components of the superior caval vein. On the left side the common cardinal vein becomes the coronary sinus, the adjacent portion of the anterior cardinal vein becomes the oblique vein of Marshal, and the posterior cardinal vein becomes the great cardiac vein (fig 5 ).

Phylogenetically, this venous arrangement is a late development. It is present only in primates and some of the other mammals, with no forerunner in other vertebrate orders. ${ }^{17}$ Persistence of bilateral superior caval veins is a common feature in cases of cardiac malformation and in $39 \%{ }^{18}$ to $43 \%{ }^{3}$ of these there is no transverse communicating vein; the left sided venous return enters directly into an atrium.

If the lower portion of the left anterior cardinal vein atrophies while the usual transverse anastomosis fails to develop, survival depends on the opening up of an alternative anastomotic pathway within the capillary plexus of that region. This seems to be a possible explanation of the anomalous subaortic position of communicating vein presently described.
The subaortic vein enters the superior caval vein below the insertion of the azygos vein and it thus $c$. connects the left anterior cardinal venous component to the right common cardinal venous component. Normally, the left brachiocephalic vein enters the superior caval vein above the insertion of the azygos $\frac{\bar{\sigma}}{\bar{c}}$. vein and the connection is between the left and the $\frac{\bar{T}}{\sigma}$ right anterior cardinal components. The anomalous $\triangle$ vein, therefore, is embryologically distinct from the normal left brachiocephalic vein as well as having a $\vec{\circ}$ different spatial pathway and different anatomical ${ }_{-}^{\circ}$ relations. In consequence, the question of termin- $\vec{\omega}$ ology could be debated at length. But, because the $\frac{\rho}{\partial}$ ultimate connections at either end are identical, it $?$ seems reasonable to refer to the structure as an? anomalous brachiocephalic vein.

Although not of clinical importance, its recognition during clinical investigation raises the

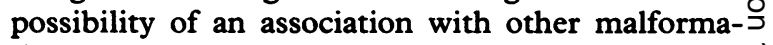
tions, especially right aortic arch, ventricular septal $\vec{c}$ defects, and right ventricular outflow obstruction. Care must be taken not to confuse the structure with ${ }^{\infty}$ other arteries or veins-notably, the central $\vec{\oplus}$ pulmonary arteries in the presence of the pulmonary ${ }^{\infty}$ atresia or a venous confluence in anomalous 0 pulmonary venous connection. ${ }^{5}$ From the surgical viewpoint, the anomalous brachiocephalic vein may hinder access to the arterial duct during ductal ligation, or obscure the field in the construction of $a \frac{2}{2}$ subclavian to pulmonary shunt. Dissection in the $\stackrel{\Omega}{\vec{P}}$ region of the duct must be performed carefully to $\frac{3}{3}$ avoid damaging a subaortic vein.

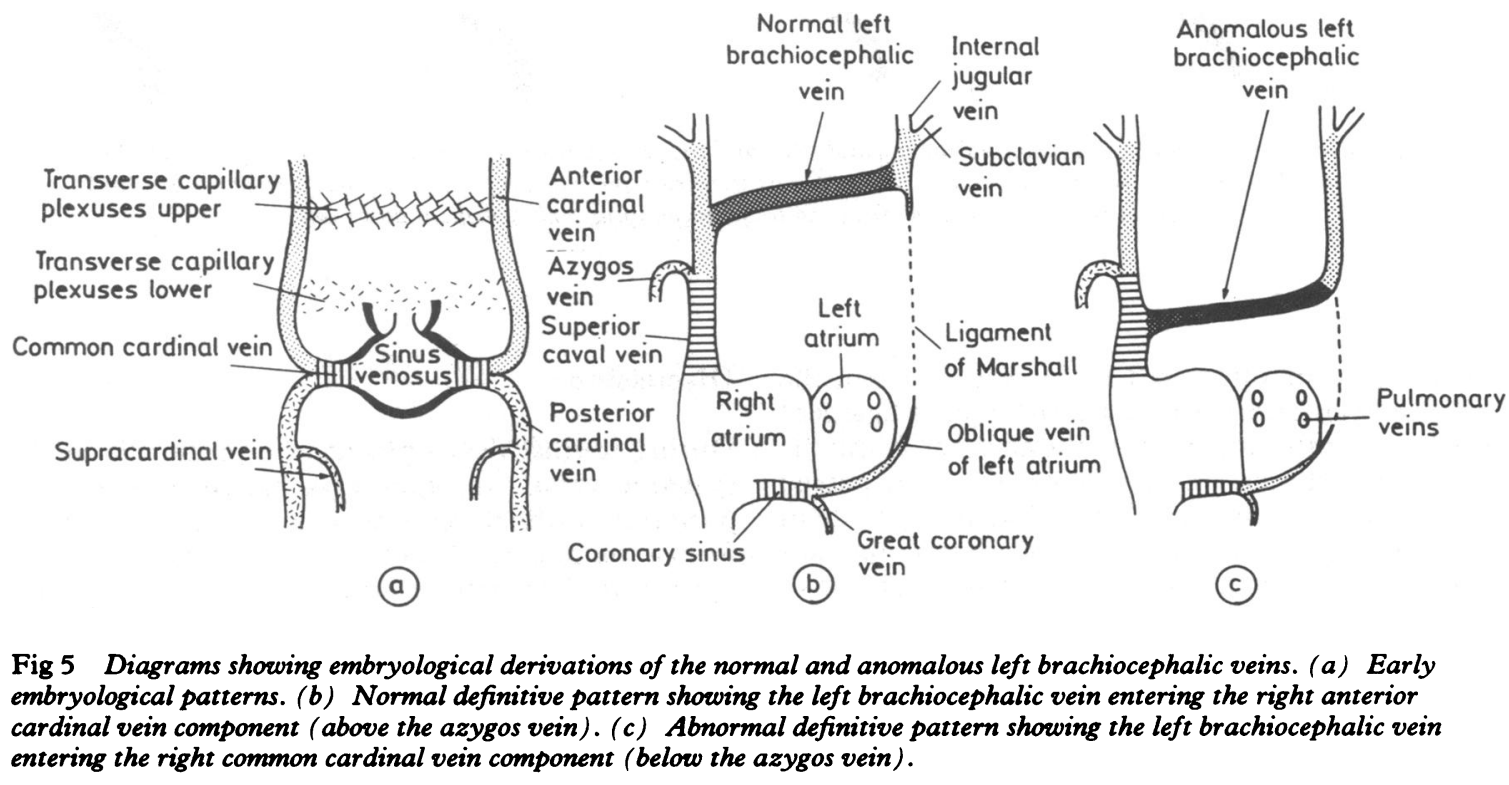
entering the right common cardinal vein component (below the azygos vein). 
We thank Dr Wilfred Nikolaizik for his valuable assistance in translating some of the references.

This study was supported, in part, by the British Heart Foundation.

\section{References}

1 Roberts JR, Dotter CT, Steinberg I. Superior vena cava and innominate veins: angiographic study. $\mathrm{Am} \mathrm{J}$ Roent 1951;66:341-52.

2 Kershner L. Zur Morphologie der Vena Cava Inferior. Anat Anz 1888;3:808-23.

3 Buirsky G, Jordan SC, Joffe HS, Wilde P. Superior vena caval abnormalities: their occurrence rate, associated cardiac abnormalities and angiographic classification in a paediatric population with congenital heart disease. Clin Radiol 1986;37:131-8.

4 Sherman FE. An atlas of congenital heart disease. London: Henry Kimpton, 1963.

5 Smallhorn JF, Zielinsky P, Freedom RM, Rowe RD. Abnormal position of the brachiocephalic vein. Am J Cardiol 1985;55:234-6.

6 Daser P. Ueber eine seltene Lage-Anomalie der vena anomyma sinistra. Anat Anz 1902;20:553-5.

7 Ghon A. Ueber eine seltene Entwicklungsstorung des Gefasssystems. Zbl Path 1908;19:242-7.

8 Nützel H. Beitrag zur Kenntnis der Missbildungen in Bereiche der oberen Holvene. Frankf $Z$ Path 1914;15:1-19.
9 Martin CP. A case of congenital abnormality of the heart with apparently an unusual abnormality of the great vessels. J Anat 1931;65:395-8.

10 Walter $\mathrm{L}$. Uber eine seltene Lageanomalie di vena anomyma sinistra webst Betrachtungen uber anomalien and Asymmetrien des Venensystems in Bereich des Kopfes und Halses. Z Anat 1931;95: 769-805.

11 Adachi B. Das Venensystem der Japaner. Anatomie der Japaner II. Tokyo: Kenkyusha, 1933:83-7.

12 Friedman SM. Report of two unusual venous abnormalities (left postrenal inferior vena cava; post-aortic left innominate vein). Anat $\operatorname{Rec} 1945 ; 92: 71-6$.

13 Yoshida Y, Fukuyama U. A case of the left brachiocephalic vein passing behind the ascending aorta. Chiba Igaku 1975;51:157-9.

14 Kitamura S, Sakai A, Nishiguchi J. A case of the left innominate vein passing behind the ascending aorta. Anat Rec 1981;201:567-72.

15 Cloez JL, Ravault F, Marçon F, Pernot C. Tronc veineux innominé en position sous-aortique. Intérêt de l'echocardiographie de contraste par voie suprasteinale. Arch Mal Coeur 1982;75:939-43.

16 Jakubczik I, Ziegler H. Seltene Anomalein der Grossen intrathoracalen Blut und lymphgefassstamme. Anat Anz 1963;112:257-68.

17 Barnett CH, Harrison RJ, Tomlinson JDW. Variations in the venous systems of mammals. Biol Rev 1958;33:442-78.

18 Winter FS. Persistent left superior vena cava. Survey of world literature and report of thirty additional cases. Angiology 1954;5:90-132. 